\title{
Pengembangan Media Pembelajaran Pengolahan dan Penyajian Makanan Indonesia Menggunakan Aplikasi Lectora Inspire
}

\author{
Dewi Rahmayanti ${ }^{1}$ \\ ${ }^{1}$ SMK Negeri 4 Kota Jambi, Jambi, Indonesia
}

\begin{tabular}{l} 
Article Info \\
\hline Article history: \\
Received Mar 30, 2020 \\
Revised Apr 14, 2020 \\
Accepted Apr 22, 2020 \\
\hline
\end{tabular}

Keywords :

Media Pembelajaran Aplikasi Lectora Inspire Siswa

\begin{abstract}
ABSTRAK
Tujuan penelitian: Penelitian ini dimaksudkan untuk menghasilkan media pembelajaran berbasis Lectora Inspire dan mengenali efektivitasnya pada siswa kelas Cookery XI di SMKN 4 Kota Jambi. Subjek penelitian adalah siswa kelas X Cookery di SMKN 4 Kota Jambi.
\end{abstract}

Metodologi: Model pengembangan penelitian disebut model ADDIE oleh Lee And Owen, yang terdiri dari 5 tahap, yaitu: Analisis, Desain, Pengembangan, Implementasi dan Evaluasi. Metode pengumpulan data adalah observasi, wawancara, kuesioner/pedoman wawancara dan dokumentasi. Penilaian kelayakan video divalidasi oleh para ahli media dan konten. Sampel dari kelas kecil adalah 15 siswa dan kelas besar adalah 30 . Teknik analisis menggunakan statistik deskriptif.

\begin{abstract}
Temuan utama: Hasil dari penelitian pengembangan adalah media pembelajaran berbasis Lectora Inspire yang digunakan dengan baik oleh siswa Kelas Cookery XI tidak hanya dalam hal kesesuaiannya dengan silabus dan rencana pelajaran tetapi juga aspek konten dan media. Validasi yang diberikan oleh validator dari pakar konten dan media menyatakan kesesuaian dalam skala "Sangat Setuju". Disimpulkan bahwa media pembelajaran berbasis Lectora Inspire dapat digunakan untuk media pembelajaran. Berdasarkan hasil validasi, media diuji ke kelas skala kecil dan mencapai $91,42 \%$ dari hasil presentasi yang dikategorikan dalam skala "Sangat Setuju". Kemudian diuji dalam uji lapangan dengan hasil presentasi $89,79 \%$ yang dikategorikan dalam skala "Sangat Setuju". Hasilnya, dinyatakan dengan jelas bahwa media pembelajaran Persiapan dan Penyajian Makanan Indonesia benar-benar digunakan sebagai media pembelajaran bagi siswa kelas Cookery XI di SMKN 4 Kota Jambi.
\end{abstract}

Keterbaruan peneltian: Keterbaruan penelitian ini adalah pengembangan media pembelajaran menggunakan aplikasi lectora untuk pembelajaran pengolahan dan penyajian makanan.

This is an open access article under the $\mathrm{CC} B Y-N C$ license

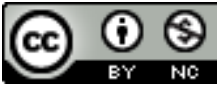

Corresponding Author:

Dewi Rahmayanti

SMK Negeri 4 Kota Jambi, Jambi, Indonesia

email : dewirahma@gmail.com

\section{PENDAHULUAN}

Pendidikan pada dasarnya adalah usaha sadar untuk menumbuhkembangkan potensi sumber daya manusia terutama peserta didik yang dilakukan dengan cara membimbing dan memfasilitasi kegiatan belajar mereka[1]. Proses yang dilakukan dalam pendidikan bertujuan tidak lain untuk meningkatkan sumber daya manusia[2]. Tujuan didirikan pendidikan salah satunya tertuang dalam Pembukaan Undang-Undang Dasar 1945 yaitu mencerdaskan kehidupan bangsa. Selain dari itu, pendidikan juga bertujuan menciptakan individu yang berakhlah mulia, berpengetahuan, memiliki potensi serta dapat menjunjung tinggi bangsa dan negaranya melalui upaya pengajaran, kegiatan, maupun pelatihan. Tujuan ini dapat tercapai apabila didukung beberapa faktor yang mempengaruhi di 
antaranya seperti kualitas pengajaran, metode pengajaran yang di pergunakan, bahan ajar yang digunakan, penyusunan materi, serta kurikulum yang digunakan [3].

Upaya pengajaran dan pelatihan itu sendiri kita kenal dengan belajar dan pembelajaran. Belajar adalah suatu proses yang menghasilkan perubahan baik tingkah laku, pengetahuan, pemahaman, keterampilan, kebiasaan sebagai usaha seseorang yang dapat diamati dan bersifat relatif konstan dan berbekas [4]. Sedangkan, pembelajaran adalah proses interaksi antara peserta didik dan guru serta sumber belajar yang tujuannya membuat peserta didik belajar atau kegiatan untuk membelajarkan peserta didik sehingga dapat mencapai tujuan yang akan dicapai oleh peserta didik dan pendidik [5]. Dalam proses belajar mengajar ada banyak faktor yang mempengaruhi tercapainya tujuan pembelajaran diantaranya pendidik, peserta didik, lingkungan, metode/teknik serta media/alat pembelajaran. Keberhasilan pembelajaran sangat dipengaruhi kelengkapan sarana atau media yang digunakan. Sebab semakin bervariasi media yang digunakan, pesan atau materi pembelajaran akan semakin optimal diterima peserta didik [6]. Dalam kaitannya dengan usaha untuk mencapai tujuan pembelajaran, media pembelajaran mempunyai peran yang sangat penting. Media pembelajaran merupakan saluran komunikasi yang berperan penting dalam penyampaian pesan untuk mencapai tujuan pembelajaran[7]. Media pembelajaran merupakan salah satu komponen pembelajaran yang mempunyai peranan penting dalam kegiatan belajar mengajar. Pemanfaatan media seharusnya merupakan bagian yang harus mendapat perhatian guru dalam setiap kegiatan pembelajaran, guru perlu mempelajari bagaimana menetapkan media pembelajaran agar dapat mengefektifkan pencapaian tujuan pembelajaran dalam proses belajar mengajar. Selain itu, media pembelajaran dapat pula meningkatkan perhatian siswa sehingga pembelajaran lebih menarik [8].

Pada kenyataannya media pembelajaran masih sering terabaikan dengan berbagai alasan, antara lain: terbatasnya waktu untuk membuat persiapan mengajar, sulit mencari media yang tepat, tidak tersedianya biaya, dan lain-lain. Hal ini sebenarnya tidak perlu terjadi jika setiap guru telah mempunyai pengetahuan dan keterampilan mengenai media pembelajaran. Guru dituntut untuk membuat suatu media pelajaran yang mampu dikuasai anak didik secara tuntas. Ini merupakan masalah yang cukup sulit yang dirasakan oleh guru. Kesulitan itu dikarenakan anak didik bukan hanya sebagai individu dengan segala keunikannya, tetapi mereka juga sebagai makhluk sosial dengan latar belakang yang berbeda. Paling sedikit ada tiga aspek yang membedakan anak didik satu dengan yang lainnya, yaitu aspek intelektual, psikologis, dan biologis. Ketiga aspek tersebut diakui sebagai akar permasalahan yang melahirkan bervariasinya sikap dan tingkah laku anak didik disekolah. Hal itu pula yang menjadikan tugas guru menjadi lebih berat dalam hal mengelola dan menyampaikan materi pelajaran dikelas. Keluhan-keluhan guru sering terlontar hanya karena masalah sukarnya membuat media untuk pembelajaran di kelas. Akibat kegagalan guru membuat media pembelajaran ,tujuan pengajaran pun sukar untuk dicapai. Hal ini kiranya tidak perlu terjadi, karena usaha yang dapat dilakukan masih terbuka lebar.

Faktor utama yang menyebabkan rendahnya capaian prestasi belajar di Indonesia adalah kurangnya keterampilan tenaga pendidik dalam pengelolaan pembelajaran. Pada umumnya, tenaga pendidik Indonesia masih menggunakan pembelajaran konvensional yang bersifat verbalistik dan proses pembelajaran sangat berpusat pada guru (teacher centered). Salah satu cara untuk meningkatkan minat siswa terhadap pelajaran dengan membuat suatu media yang menarik untuk pelajaran tersebut. Upaya tersebut terkait dengan berbagai komponen yang terlibat dalam pembelajaran, salah satu diantaranya adalah dengan pemanfaatan media pembelajaran. Penggunaan media dalam proses pembelajaran secara signifikan mampu meningkatkan pencapaian hasil belajar [9].

Berdasarkan hasil pengamatan yang telah dilakukan oleh peneliti di SMKN 4 Kota Jambi pada mata pelajaran pengolahan dan penyajian makanan Indonesia diketahui bahwa pada mata pelajaran ini tuntut dengan nilai ketuntasan minimal 72 untuk pengetahuan dan untuk nilai keterampilan 73. Berdasarkan hasil pengamatan dan observasi di dalam kelas selama proses belajar mengajar metode pembelajaran yang digunakan masih secara konvensional yaitu berupa ceramah dan tanya jawab tanpa adanya media yang relevan, akibatnya siswa kurang memperhatikan dan kurang berminat pada pelajaran tersebut dikarenakan banyak siswa yang bosan terhadap penjelasan guru. Dengan kondisi seperti ini maka pelaksanaan pembelajaran kurang tercapai secara maksimal. Hal ini dapat di lihat dari hasil analisis tes formatif dan sumatif nilai mata pelajaran pengolahan makanan Indonesia sekitar 40\% masih belum mencapai nilai Ketuntasan belajar.

Dari hasil wawancara dan observasi dengan siswa dan guru SMKN 4 jurusan jasa boga sekitar 97\% mereka menghendaki adanya media pembelajaran yang relevan dengan mata pelajaran produktif kejuruan jasa boga agar dapat meningkatkan minat belajar siswa terhadap pelajaran produktif. Berdasarkan hal tersebut peneliti mencoba membuat media yang dapat membantu meningkatkan hasil belajar siswa terhadap mata pelajaran produktif kejuruan yaitu pengolahan dan penyajian makanan Indonesia berupa pengembangan media pembelajaran berbasis komputer dengan tujuan agar siswa lebih memahami materi pelajaran. Bagaimanapun media pembelajaran memiliki peran yang srategis dalam proses pembelajaran. Pemanfaatan media pembelajaran berbasis komputer merupakan kebutuhan mutlak dalam dunia pendidikan untuk masa sekarang dan masa yang akan datang, sehingga sekolah benar benar menjadi ruang belajar dan tempat siswa mengembangkan kemampuannya secara optimal. Disini peneliti tertarik untuk mengembangkan bahan ajar berbasis multimedia dengan menggunakan aplikasi lectora inspire, dimana multimedia ini nantinya dapat dipergunakan oleh siswa dalam proses pembelajaran. 
Dalam teknologi pembelajaran, belajar menyangkut adanya perubahan yang relatif permanen pada pengetahuan dan prilaku seseorang karena pengalamannya[10]. Dalam teori belajar dan pembelajaran menyatakan bahwa belajar adalah proses yang dilakukan oleh manusia untuk mendapatkan aneka ragam kemampuan, keterampilan dan sikap, yang mana semuanya dapat di peroleh secara bertahap dan berkelanjutan mulai dari masa bayi sampai masa tua melalui serangkaian proses belajar sepanjang hayat. Rangkaian proses belajar itu dilakukan dalam bentuk keterlibatannya dalam pendidikan informal, non formal dan formal. Media pembelajaran identik artinya dengan pengertian keperagaan yang berasal dari kata raga yaitu bentuk yang dapat di raba, dilihat, didengar, diamati melalui panca indera. Media pembelajaran digunakan dalam rangka hubungan (komunikasi) dalam proses pembelajaran antara pengajar dan pembelajar. Media pembelajaran adalah semacam alat bantu dalam proses pembelajaran, baik di dalam kelas maupun di luar kelas. Dalam pengertian lain, media pembelajaran merupakan perantara (medium, media) dan di gunakan dalam rangka pendidikan dan pengajaran. Dengan demikian, media pembelajaran mengandung aspek alat dan teknik yang sangat erat kaitannya dengan metode mengajar.

Media pembelajaran adalah sarana, metode, teknik untuk lebih mengefektifkan komunikasi dan interaksi antara pengajar dengan pembelajar di kelas. Jadi media adalah sebuah alat yang mempunyai fungsi menyampaikan pesan. Media pembelajaran adalah sebuah alat yang berfungsi untuk menyampaikan pesan pembelajaran. Sedangkan pembelajaran adalah proses komunikasi antara pengajar, pembelajar dan bahan ajar. Komunikasi tidak akan berjalan dengan baik, tanpa bantuan sarana penyampaian pesan atau yang di sebut dengan media. Pengertian lain tentang media menurut the association for educational communication and technology (AECT 1997) dalam kreatif mengembangkan media pembelajaran mengatakan bahwa media adalah apa saja yang di gunakan untuk menyalurkan informasi. Media merupakan alat yang dipergunakan untuk menyalurkan pesan dan informasi dari pengirim pesan kepada penerima pesan. Pembelajaran yang menggunakan teknologi informasi dan komunikasi atau menggunakan multimedia disebut dengan media pembelajaran berbasis multimedia interaktif[11]. Penggunaan aplikasi multimedia dalam pembelajaran akan meningkatkan motivasi, efisiensi, dan memfasilitasi belajar aktif, serta dapat mengembangkan keterampilan proses sains siswa yang pada gilirannya akan memberikan kontribusi positif terhadap hasil belajar siswa [12].

Lectora Inspire adalah perangkat lunak Authoring Tool untuk pengembangan konten e-learning yang di kembangkan oleh Trivantis Corporation. Lectora Inspire merupakan salah satu software yang dapat di gunakan untuk mengembangkan media pembelajaran. Lectora Inspire dapat digunakan dengan menggabungkan materi pelajaran, foto, video, menggabungkan gambar dan screen capture [13]. Diharapkan dengan dikembangkan media pembelajaran berbasis multimedia yang menarik dan efektif dapat meningkatkan hasil belajar peserta didik, karena dalam media pengembangan aplikasi lectora tergambar komponen komponen yang meliputi: petunjuk, tujuan, uraian, isi, daftar bacaan dan soal latihan. Dengan menggunakam lectora inspire, materi pelajaran didesain semenarik mungkin, dapat menampilkan video, serta gambar-gambar animasi yang berhubungan dengan materi pelajaran agar peserta didik lebih memperhatikan apa yang disampaikan oleh guru. Proses pembelajaran akan lebih menyenangkan dan bermakna, sehingga berpengaruh pada peningkatan prestasi belajar peserta didik [14]. Media ajar berbasis ICT dengan aplikasi Lectora Inspire memungkinkan adanya optimalisasi keterlibatan seluruh indra siswa dapat menyajikan sebuah tampilan berupa teks dan multidimensional dengan simpulan secara interaktif [15].

Alasan menggunakan aplikasi lectora inspire adalah media ini merupakan salah satu media pembelajaran yang berbentuk multimedia yang sekarang lagi gencar gencarnya di galakkan di dunia pendidikan yang menggunakan sentuhan tehnologi di dalam proses belajar pembelajaran. Dengan media pengembangan aplikasi lectora ini di harapkan dapat meningkatkan minat belajar siswa dan membantu guru untuk mengurangi waktu penyajian materi sehingga memperbanyak waktu pembimbingan kepada siswa

\section{METODE PENELITIAN}

Pengembangan media pembelajaran pengolahan dan penyajian makanan Indonesia, merupakan serangkaian proses atau kegiatan yang di lakukan untuk menghasilkan produk media pembelajaran berdasarkan teori pengembangan yang sudah ada. Model pengembangan merupakan dasar untuk mengembangkan media pembelajaran yang akan di hasilkan. Pengembangan media pembelajaran pengolahan dan penyajian makanan Indonesia dengan menggunakan aplikasi lectora inspire, dalam rancangannya menggunakan model desain pengembangan Lee dan Owens [16]. model pengembangan ini dipilih karena bersifat:

a. Prosedural, yaitu model yang bersifat deskriptif, menunjukkan langkah langkah yang jelas dan cermat untuk menghasilkan produk

b. Tahap pengembangan dalam rancangan desain ini dirancang khusus untuk pembelajaran berbasis multimedia, yang sesuai dengan produk pengembangan media yang akan di kembangkan.

Secara garis besar, model pengembangan desain Lee dan Owen terdiri dari 5 desain yaitu: (1) Analisis, (2) Desain, (3) Pengembangan, (4) Implementasi, dan (5) Evaluasi. Sebagai gambaran 5 langkah tersebut disajikan pada gambar berikut. 


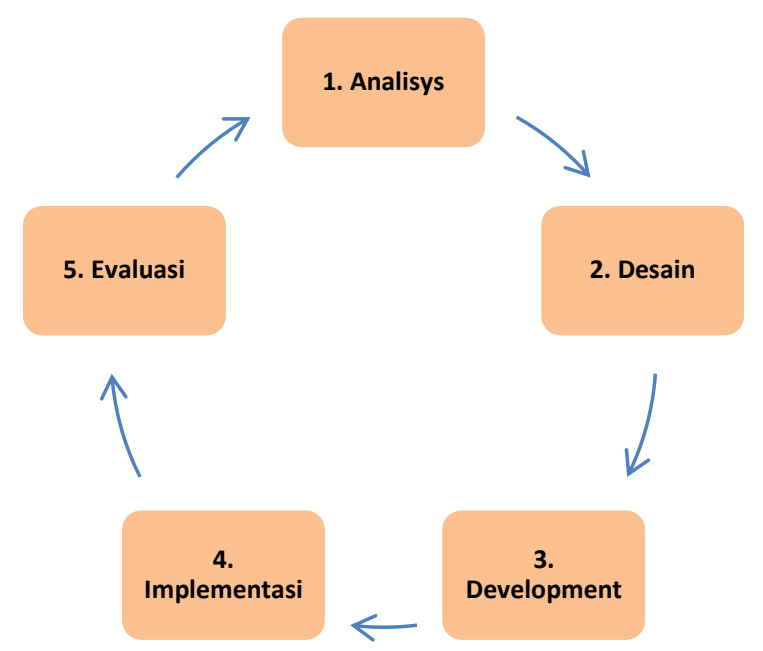

Gambar 1. Desain Pembelajaran ADDIE

\section{Prosedur Pengembangan}

Berdasarkan model pengembangan Lee and Owens, prosedur pengembangan pada penelitian ini terdiri dari 5 tahap, yaitu:

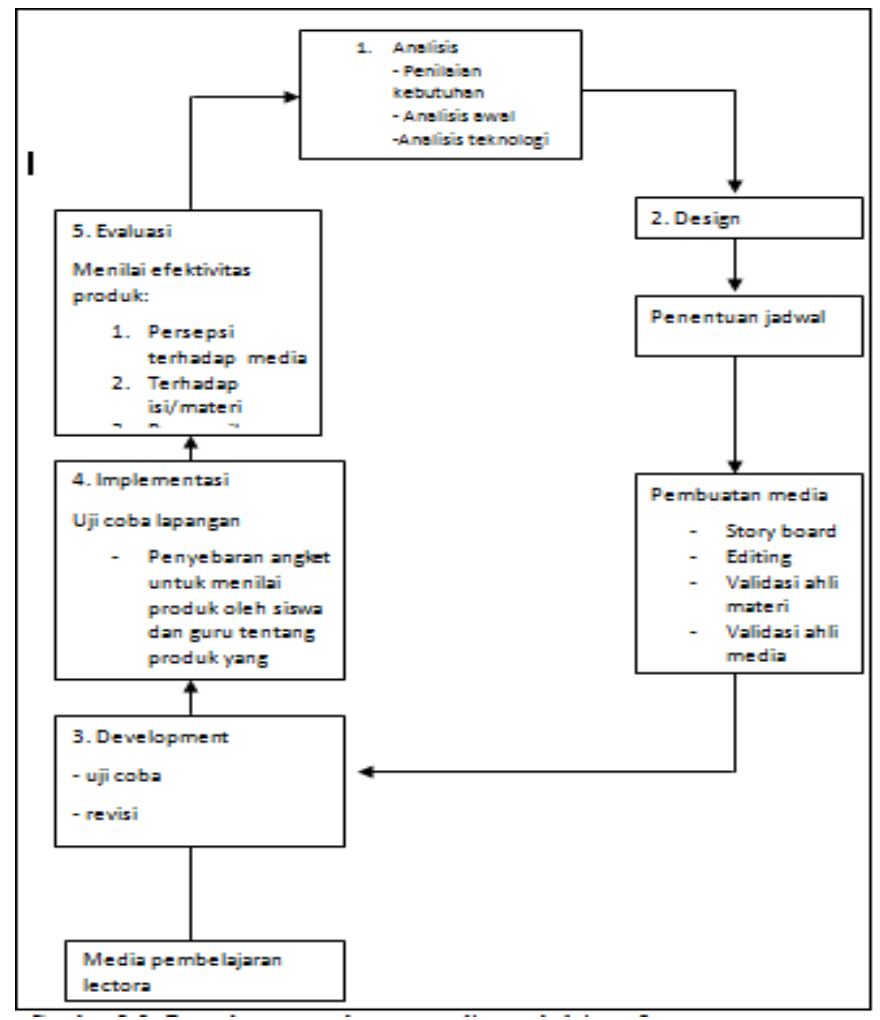

Gambar 2. Prosedur Pengembangan Penelitian

Tahap pertama pada pengembangan aplikasi lectora inspire pada mata pelajaran pengolahan dan penyajian makanan indonesia yaitu tahap pra produksi. Pada tahap ini peneliti menentukan kontent apa saja yang akan di sesuaikan pada aplikasi pembelajaran. Berdasarkan hasil analisis terhadap kebutuhan pembelajaran di SMKN 4 Kota Jambi, pengembang akan mengembangkan aplikasi pembelajaran yang mengandung konten, yaitu Silabus, Rpp, Materi Pelajaran, tes dan referensi. Tampilan aplikasi akan di desain sedemikian rupa sehingga mudah di pahami oleh siswa dan guru di karenakan kemampuan menggunakan tehnologi multimedia setiap pengguna berbeda beda. 
Tahap kedua yaitu tahap produksi, pembuatan aplikasi pembelajaran mulai dilakukan sesuai rancangan yang telah di buat. Pengembang juga memperhatikan desain tampilan sehingga aplikasi terlihat menarik. Namun demikian pengembang tidak memasukkan unsur gambar yang berlebihan sehingga nanti aplikasi ini mudah di akses.

Tahap ketiga yaitu pasca produksi, pada tahap ini setelah aplikasi pembelajaran selesai di buat, selanjutnya di lakukan validasi oleh tim ahli media, guna melihat kelayakan media aplikasi lectora yang di buat. Selain itu validasi di lakukan untuk memvalidasi desain media dan struktur konten media. Pengumpulan data dari validator yang di peroleh dari angket yang di isi oleh validator.

\section{HASIL DAN PEMBAHASAN}

Media pembelajaran lectora pada mata pelajaran pengolahan dan penyajian makanan Indonesia dikembangkan berdasarkan analisis kebutuhan yang telah dilakukan dengan melaksanakan observasi dikelas dan menyebar angket kepada para siswa kelas XI SMKN 4 Kota Jambi. Setelah mengikuti prosedur pengembangan berdasarkan desain ADDIE yang dikembangkan oleh Lee and Owen, maka pengembangan ini telah melewati tahapan proses analisis, perancangan, pengembangan, evaluasi dan penerapan produk yang telah memenuhi kriteria validasi yang telah dilakukan oleh validator ahli media dan ahli materi.

Produk yang dihasilkan adalah media pembelajaran pengolahan dan penyajian makanan Indonesia dengan aplikasi lectora pada siswa kelas XI SMKN 4 Kota Jambi. Media ini dapat menampilkan unsur materi pelajaran, unsur gambar, unsur suara, unsur video dan tes secara bersamaan dalam satu aplikasi. Materi media diperoleh dari buku buku pelajaran siswa jasa boga kelas XI, unsur gambar di hasilkan dari hasil praktik siswa yang telah dilaksanakan sebelumnya dan juga di dapat dari download internet, sedangkan unsur suara dan video didapat dari hasil proses syuting pengambilan gambar yang dilakukan pengembang dalam pembuatan video yang dilaksanakan di indoor dan out door yang telah dilaksanakan dan telah melalui proses editing.

Pengembangan media pembelajaran pengolahan dan penyajian makanan indonesia dengan aplikasi lectora pada siswa kelas xi jasa boga SMKN 4 kota Jambi bertujuan untuk: 1). Menghasilkan produk berupa media pembelajaran pada materi pengolahan dan penyajian makanan Indonesia dengan menggunakan aplikasi lectora Inspire yang menarik untuk pembelajaran kelas XI Jasa Boga SMKN 4 Kota Jambi 2). Mengetahui respon siswa dan guru terhadap produk yang di kembangkan dalam bentuk media pembelajaran menggunakan aplikasi lectora inspire pada pelajaran pengolahan dan penyajian makanan Indonesia 3). Mengetahui efektifitas materi media pembelajaran yang di kembangkan dengan pada materi pengolahan dan penyajian makanan Indonesia yang di ukur dari peningkatan hasil belajar siswa. Sebelum dilakukan pembuatan media dilakukan studi pendahuluan terhadap siswa jasa boga SMKN 4 kota jambi. Studi pendahulaun dilakukan dengan cara observasi dan wawancara. Observasi dilakukan sebelum melakukan penelitian yaitu bulan 2016. Pada observasi ini disepakati kelas yang dijadikan sebagai ujicoba angket dan penelitian. Hasil observasi dan wawancara dilakukan peneliti sebagai berikut:

1). Observasi. Dari hasil observasi maka dapat diketahu situasi nyata kegiatan belajar mengajar [17-19]. Metode mengajar yang digunakan saat kegiatan belajar mengajar pada mata pelajaran pengolahan dan penyajian makanan indonesia kelas xi Jasa boga smkn 4 kota jambi masih menggunakan metode demostrasi, sehingga situasi kelas kurag terkontrol, siswa kesulitan mengukti pelajaran, sehingga nilai ketuntasan belajar tidak tercapai siswa tidak tercapai

2). Wawancara dari hasil wawancara kepada guru dan siswa maka dapat diketahui bahwa ketersediaan media pembelajaran dan kebutuhan terhadap pengembangan media untuk siswa pada mata pelajaran pengolahan dan penyajian makanan indonesia masih belum ada [20-22]. Berdasarkan hasil wawancara maka dapat disimpulkan bahwa keterbatasan media pembelajaran menyebabkan kurang optimalnya proses dan hasil pembelajaran, sehingga perlu dikembangkan media pembelajaran berupa media lectora pada siswa kelas xi jasa boga smkn 4 Kota Jambi

Setelah melakukan analisis kebutuhan produk, maka langkah selanjutnya adalah mengkaji pustaka yaitu mengumpulkan data data, buku, serta referensi yang mendukung dalam pengembangan media pembelajaran pengolahan dan penyajian makanan indonesia dengan aplikasi lectora pada siswa kelas xi smkn 4 kota jambi. Kajiam pustaka digunakan sebagai dasar dalam mengembangkan produk awal media pembelajaran pengolahan dan penyajian makanan indonesia. Sumber referensi untuk pemgembangan media didapat dari sumner yang relevan, yaitu:

1) Buku "Media Pembelajaran. Oleh Arsyad Azhar

2) Buku "Kreatif Mengembangkan Media Pembelajaran. Oleh Arsyhar Rayandra

3) Buku "Multi Media Pembelajaran Dengan Lectora. Oleh Mas'ud Muhammad

4) Buku Orientasi baru dalam Psikologi Pendidikan. Oleh Jamaris Martini

Sedangkan untuk materi di dapat dari:

1) Buku Resep Masakan Indonesia. Oleh Tim Yasa Boga dan GPU

2) Buku Mengolah Makanan Indonesia. Oleh Tim Pariwisata SMK

3) Buku Restoran Jilid 1. Oleh Prihastuti Ekawatiningsih, kokom Komariah, Sutriyati Purwanti

4) Buku Restoran Jilid 2. Oleh Prihastuti Ekawatiningsih, kokom Komariah, Sutriyati Purwanti 
Validasi media dilakukan dinilai oleh validator untuk media pembelajaran menggunakan aplikasi lectora untuk menilai media dari aspek fungsi dan manfaat media, aspek visual media video, aspek audio, aspek tipografi, aspek bahasa sebagai media pembelajaran.. Hasil penilaian dari validator di analisis dengan menggunakan skala likers dengan respon skala 4, dengan alternatif pilihan sangat setuju, setuju, tidak setuju dan sangat tidak setuju. Skor jawaban oleh ahli media menunjukkan skor berdasarkan presentasi kelayakan yaitu untuk data kuantitatif, penentuan klasifikasi validasi oleh ahli media didasarkan pada rerata skor jawaban. Data di analisis dan diolah secara deskriptif menjadi data interval menggunakan skala Likert. Ahli media yang menjadi validator dalam penelitian ini adalah Bapak Dr. Martinis Yamin, M.Pdi, beliau adalah dosen Magister Tehnologi Pendidikan Pasca Sarjana Universitas Jambi.

Validasi materi yang dinilai oleh validator untuk media pembelajaran menggunakan aplikasi lectora sudah relevan dengan KI dan KD, silabus, materi pembelajaran, bahasa yang dipergunakan pada aplikasi lectora. Hasil penilaian dari validator di analisis dengan menggunakan skala likers dengan respon skala 4, dengan alternatif pilihan sangat setuju, setuju, tidak setuju dan sangat tidak setuju. Skor jawaban oleh ahli materi menunjukkan skor berdasarkan presentasi kelayakan yaitu untuk data kuantitatif, penentuan klasifikasi validasi oleh ahli media didasarkan pada rerata skor jawaban. Data di analisis dan diolah secara deskriptif menjadi data interval menggunakan skala Likert. Ahli materi menilai dari aspek materi yang berkaitan dengan relevansi materi dengan KI, KD, Silabus, kualitas materi, bahasa, video demonstrasi memasak sebagai media pembelajaran. Ahli media yang menjadi validator dalam penelitian ini adalah Bapak Dr. Suratno, M.Pd, beliau adalah dosen Magister Tehnologi Pendidikan Pasca Sarjana Universitas Jambi. Data validasi materi diperoleh dengan cara memberikan media Aplikasi lactora beserta intrumen penilaian. Ahli materi mengisi angket instrumen dengan cara menceklist penilaian yang tertera di lembar penilaian serta memberikan komentar dan saran guna perbaikan media aplikasi lectora.

Tahapan dalam pengembangan media pembelajaran pengolahan dan penyajian makanan Indonesia dengan menggunakan aplikasi lectora dilakukan dengan beberapa tahapan kegiatan yaitu: tahap analisis, pembuatan story board, pembuatan produk dan Validasi, kegiatan revisi produk. Tahapan selanjutnya adalah membuat story Board produk pengembangan media pembelajaran pengolahan dan Penyajian Makanan Indonesia. Story board adalah diagram alur cerita aplikasi yang akan di kembangkan. Pada story board tergambar jelas bagian bagian dari produk pengembangan media pembelajaran.

Selanjutnya pengembangan aplikasi lectora inspire pada mata pelajaran pengolahan dan penyajian makanan indonesia yaitu tahap pra produksi. Pada tahap ini peneliti menentukan kontent apa saja yang akan di sesuaikan pada aplikasi pembelajaran. Berdasarkan hasil analisis terhadap kebutuhan pembelajaran di SMKN 4 Kota Jambi, pengembang akan mengembangkan aplikasi pembelajaran yang mengandung konten, yaitu Silabus, Rpp, Materi Pelajaran, tes dan referensi. Tampilan aplikasi akan di desain sedemikian rupa sehingga mudah di pahami oleh siswa dan guru di karenakan kemampuan menggunakan tehnologi multimedia setiap pengguna berbeda beda.

Berikutnya yaitu tahap produksi, pembuatan aplikasi pembelajaran mulai dilakukan sesuai rancangan yang telah di buat. Pengembang juga memperhatikan desain tampilan sehingga aplikasi terlihat menarik. Namun demikian pengembang tidak memasukkan unsur gambar yang berlebihan sehingga nanti aplikasi ini mudah di akses. Terakhir yaitu tahap pasca produksi, pada tahap ini setelah aplikasi pembelajaran selesai di buat, selanjutnya di lakukan validasi oleh tim ahli media, guna melihat kelayakan media aplikasi lectora yang di buat.

Selanjutnya setelah di validasi oleh para validator, kegiatan yang dilakukan adalah menguji cobakan produk hasil pengembangan media pembelajaran pengolahan dan penyajian masakan indonesia dengan menggunakan aplikasi lactora inspire di SMK 4 janbi. Ujicoba dan revisi dilakukan untuk mengumpulkan data tentang kualitas aplikasi guna menunjang pembelajaran agar lebih baik dan efektif. Adapun tahapan dari implementasi yaitu penyebaran angket untuk menilai produk aplikasi.

Kelayakan media di ujicobakan pada siswa kelas XI Jasa Boga SMKN 4 , Kelurahan Sungai Puteri Kecamatan Telanaipura Kota Jambi. Siswa yang dilibatkan dalam ujicoba terdiri dari 30 orang siswa dengan rincian sebagai berikut:

1) Uji coba kelompok kecil

Pada ujicoba kelompok kecil jumlah siswa yang dilibatkan berjumlah 15 orang yang dipilih secara acak dan terdiri dari 5 orang laki laki dan10 orang perempuan tengan tingkat kemampuan berbeda.

2) Ujicoba lapangan

Siswa yang dilibatkan dalam ujicoba lapangan berjumlah 30 orang yang dipilih secara acak. Ujicoba lapangan bertujuan untuk melihat aspek pembelajaran, aspek daya tarik, aspek penilaian. Pada ujicoba lapangan ini dilaksanakan juga observasi oleh teman sejawat untuk memperkuat data yang diperlukan dalam aspek ketertarikan, aspek kemudahan, aspek efisiensi dan efektifitas multimedia interaktif yang dihasilkan pada penelitian ini.

Berdasarkan hasil penelitian yang telah dilakukan pada ujicoba kelas kecil data yang di dapat bahwa responden yang telah di presentasikan dalam bentuk persen bahwa media pembelajaran pengolahan dan penyajian makanan Indonesia dengan aplikasi lectora pada kelas XI Jasa boga SMKN 4 Kota jambi memperoleh nilai 91,42\% 
dengan klasifikasi sikap "Sangat Setuju" bahwa media pembelajaran dengan aplikasi lectora dinyatakan layak sebagai media pembelajaran. Dari hasil ujicoba lapangan data yang di dapat bahwa responden yang telah di presentasikan dalam bentuk persen bahwa media pembelajaran pengolahan dan penyajian makanan Indonesia dengan aplikasi lactora pada kelas XI jasa boga SMKN 4 Kota jambi memperoleh nilai 89,79 \% dengan klasifikasi sikap "Sangat Setuju" bahwa media pembelajaran dengan aplikasi lectora dinyatakan layak sebagai media pembelajaran.

Selanjutnya dapt diperoleh kesimpulan bahwa media pembelajaran pengolahan dan penyajian makanan indonesia pada kelas xi jasa boga smkn 4 kota Jambi dapat dikatakan "layak"sebagai media dan dapat digunakan dalam proses belajar mengajar dalam mata pelajaran pengolahan dan peyajian makanan Indonesia.

\section{KESIMPULAN}

Berdasarkan hasil validasi yang telah dilakukan oleh ahli media dan ahli materi pada mata pelajaran Pengolahan dan Penyajian Makanan Indonesia, serta uji coba lapangan kelompok kecil dan kelompok besar, bahwa pengembangan produk media pembelajaran dengan aplikasi Lectora Inspire di gunakan untuk pemenuhan kebutuhan siswa terhadap kualitas belajar yang bermakna.

Dari keseluruhan proses rancangan sampai kepada penggunaan media pembelajaran yang dikembangkan dapat ditarik beberapa kesimpulan sebagai berikut

1. Telah diperoleh suatu pengembangan berupa multimedia Lectora Inspire yang dapat digunakan oleh siswa kelas XI Jasa boga SMKN 4 kota Jambi. Produk ini telah di lengkapi dengan aplikasi yang dapat meningkatkan minat siswa terhadap pelajaran.

2. Pengembangan media pembelajaran pengolahan dan penyajian makanan dengan menggunakan aplikasi Lectora Inspire berdasarkan pengembangan Lee Dan Owens (ADDIE) ini telah melalui berbagai tahapan proses, dimulai dari tahap Analisis yaitu tahap kebutuhan siswa, karakteristik peserta didik dan analisis tehnologi. Design, tahap ini dimulai dari mendesain media, menyiapkan materi yang cocok bagi pembelajaran siswa kelas XI. Lalu tahap Development, pada tahap ini produk mulai di kembangkan dengan memuat aplikasi media pembelajaran yang dimulai dari mengembangkan story board yang telah di rancang . lalu selanjutnya dilakukan tahap Implementasi pada tahap ini produk di validasi oleh ahli media dan ahli materi dengan mengisi angket yang telah di sediakan. Lalu dilakukan penelitian yang dilaksanakan di SMK N 4 Kota Jambi pada siswa kelas XI jurusan Jasa boga, yang kemudian produk digunakan oleh siswa untuk di ujicoba. Ujicoba dilakukan 2 tahapan yaitu pada ujicoba kelompok kecil dan ujicoba lapangan. Selanjutnya produk di Evaluasi untuk mengetahui kemanfataan dan keefektifan hasil produk yang di dapat digambarkan dengan nilai responden. kelompok kecil dengan nilai 91,42\% dengan klasifikasi sikap "Sangat setuju" dan hasil dari uji coba lapangan yaitu 89,79\% dengan klasifikasi sikap "Sangat Setuju". Sehingga dapat di tarik kesimpulan media pembelajaran dengan menggunakan aplikasi lactora ini sudah dapat dikatakan layak sebagai media pembelajaran bagi siswa.

\section{UCAPAN TERIMA KASIH}

Peneliti mengucapkan terimakasih kepada Universitas Jambi yang telah mendukung dan memberikan fasilitas kepada peneliti untuk menyelesaikan penelitian. Pihak sekolah SMKN 4 Kota Jambi yang telah memberikan kesempatan kepada peneliti untuk melakukan penelitian sehingga terlaksana dengan baik serta pihakpihak lain yang telah berkontribusi dalam penelitian ini.

\section{REFERENSI}

[1] Astalini., D. A. Kurniawan., dan A. D. Putri, "Identifikasi Sosial dari IPA, Ketertarikan Menambah Waktu Belajar IPA, dan Ketertarikan Berkarir di Bidang IPA Siswa SMP se-Kabupaten Muaro Jambi”, Jurnal Tarbiyah: Jurnal Ilmiah Kependidikan, vol. 7, no.2. 2018

[2] A. Widiastuti., dan M. N. Wangid, "Pengembangan Multimedia Lectora Pada Pembelajaran Tematikintegratif Berbasis Character Building Bagi Siswa Kelas Iv SD”. Jurnal Pendidikan Karakter, vol. 5, no. 2. 2015

[3] Astalini., D. A. Kurniawan., dan Sumaryanti, "Sikap Siswa Terhadap Pelajaran Fisika Di SMAN Kabupaten Batangkhari”, Jurnal Ilmu Pendidikan Fisika, vol. 3, no. 2. 2018

[4] L. Hartati, "Pengaruh Gaya Belajar Dan Sikap Siswa Pada Pelajaran Matematika Terhadap Hasil Belajar Matematika", Jurnal Formatif, vol. 3, no. 3, 2015 ISSN: 2088-351X. 2015

[5] A. S. Nugraha, "Peningkatan Hasil Belajar Ipa Dengan Model Problem Based Learning Berbantuan Media Mind Mapping Kelas 5", e-jurnal mitra pendidikan, vol 1, no 5. 2017 
[6] N. M. Shalikhah, "Pemanfaatan Aplikasi Lectora Inspire Sebagai Media Pembelajaran Interaktif”. Jurnal Cakrawala, vol. 9, no. 1.2016

[7] I. N. W. Astawa, "Pengembangan Multimedia Pembelajaran Interaktif Mata Pelajaran Ipa Untuk Meningkatkan Prestasi Belajar Siswa Kelas Vii”, e-Journal Edutech Universitas Pendidikan Ganesha Jurusan Teknologi Pendidikan, vol. 5, no.2. 2016

[8] N. Ismail, "Pemanfaatan Media Kit Oleh Guru Dalam Pembelajaran IPA Untuk Meningkatkan Hasil Belajar Siswa di SMP Negeri 4 Kota Singkawang”. Jurnal Ilmu Pengetahuan Fisika., vol. 1, no. 1, 2016

[9] R. Arsyhar, "Kreatif Mengembangkan Media Pembelajaran”, Jakarta: Gaung Persada . 2010

[10] R. E. Mayer, "Multi Media Learning”, Prinsip prinsip dan Aplikasi Yogyakarta. PT. Pustaka Pelajar. 1982

[11] S. Prasetyo, "Pengembangan Media Lectora Inspire dalam Pembelajaran Sains di Madrasah Ibtidaiyah". Jurnal Pendidikan Islam, vol. 4, no. 02, pp. 319-337. 2015

[12] Z. Yoto., dan K. Wiyono, "Pengembangan Multimedia Interaktif Pembelajaran Teori Kinetik Gas Berbantuan Lectora Inspire Untuk Siswa Sekolah Menengah Atas (SMA)”, Jurnal Inovasi Dan Pembelajaran Fisika, vol. 2, no. 2, 2015

[13] M. Muhammad, "Membuat Multi Media Pembelajaran Dengan Lectora", Yogyakarta. Penerbit Pustaka Shonif, 2012

[14] N. M. Shalikhah., A. Primadewi., dan M. S. Iman, "Media Pembelajaran Interaktif Lectora Inspire Sebagai Inovasi Pembelajaran. Warta Lpm, vol. 20, no. 1, 2017

[15] H. M. Zulfiati, "Pengaruh Pembelajaran Ips Berbasis Ict (Information And Communications Technology) Dengan Aplikasi Lectora Inspire Dalam Meningkatkan Hasil Belajar Siswa", JIPSINDO, vol. 1, vol. 1, 2014

[16] W. L. William., D. L. Owens, "Multi-Based instructional Design computer -based traning Web-based traning Distance broadcast training performance-based solutions second edition". By pfeiffer San Fransisco, 2004

[17] Maison., Astalini., D. A. Kurniawan., R. Perdana., L. Anggraini, "The Phenomenon of Physicology Senior High School Education: Relationship of Students' Attitudes towards Physics, Learning Style, Motivation. Universal Journal of Educational Research. vol. 7, no. 10, pp. 2199-2207, 2019

[18] R. Rahmayeni, "Kerja keras siswa dalam pelajaran sains”, Journal Evaluation in Education, vol. 1, no. 1, pp. 27-33, 2020

[19] M. Corry, "Identifikasi religiusitas siswa di sma adhyaksa 1 jambi”, Journal Evaluation in Education, vol. 1, no. 1, pp. 1520, 2020

[20] N. Neldawati, "Deskripsi lingkungan belajar siswa terhadap mata pelajaran fisika di sma ferdy ferry putra kota jambi", Journal Evaluation in Education, vol. 1, no. 1, pp 1-7, 2020

[21] S. Hasrani, "Kreativitas siswa dalam mata pelajaran ipa", Journal Evaluation in Education, vol. 1, no. 1, pp. 21-26, 2020

[22] Astalini., D. A. Kurniawan., L. Anggraini, "Correlation between confidence with attitude toward science in secondary school in Indonesia”. Beder Scientific Journal of Education Sciences (BJES), vol. 20, no. 1, pp. 30-45, 2020 